\title{
RESPONDING WITH DAO: EARLY DAOIST ETHICS AND THE ENVIRONMENT
}

\section{Eric Sean Nelson}

Department of Philosophy, University of Massachusetts, Lowell

\section{Introduction}

This essay responds to recent scholarly literature that is skeptical of the potential environmental significance of Daoism. ${ }^{1}$ Its argument is that "early Daoist" texts such as the Laozi and the Zhuangzi and later sources such as the Yuan Dao, are salient to contemporary ecological issues by indirectly suggesting a critical model for environmental ethics. ${ }^{2}$ The phrase "early Daoism," which some scholars prefer to portray as proto-Daoism, designates the overlapping yet divergent tendencies found in the Daodejing and Zhuangzi. ${ }^{3}$ Although I avoid the problematic expression "philosophical Daoism" (Daojia 道家), which retrospectively ascribes a common identity to the collection of texts associated with Laozi and Zhuangzi and questionably distinguishes this position from a later "religious Daoism" (Daojiao 道教), I presuppose that Daoist texts of any provenance can have a philosophical import and be philosophically examined.

The Daodejing and the Zhuangzi are not relevant to environmental issues by contributing specific scientific research, political policies, or activist initiatives. It would be anachronistic to have such expectations of ancient texts. What early Daoism does suggest is a phenomenology of the experiential orientation and disposition of the embodied heart/mind (xin 心) that is timely in being fittingly attuned with its world. Daoism, interpreted in the light of contemporary thought, offers a philosophical basis for a non-reductive naturalistic ethics in the widest sense of these words. Whereas the naturalism of early Daoism can be glimpsed in its openness to natural phenomena, without reducing things to a specific doctrine or essence of what constitutes nature or the natural, ethics signifies its cultivation of life as the lived and unforced performative enactment of responsive freedom. Although classical Daoist texts seem to reject "ethics," provided that ethics consists of rules, norms, and conventions organizing hierarchical and authority-driven social relations, early Daoism is not so much an anti-ethical and aesthetic nihilism as it is an alternative way of living with things. This naturalistic and anti-conventional approach to the ethical can be described preliminarily as an embodied receptivity to the myriad or ten thousand things (wanwu 萬物) themselves in their specificity, parity, and interconnectedness.

\section{Daoism, Ethics, and the Environment: Problems and Possibilities}

The argument that early Daoism undermines essentialism is apt if its "essences" are dynamic processes, contrasting with static characteristics and properties, calling for 
vigilance against the reification that turns self-generating transformative phenomena into unchanging substances like "nature" and "being." 5 Yet the aspect of Daoism identified as "anti-essentialism" does not therefore imply the transition from essentialism to constructivism, for which signification is a mental, linguistic, or social product. To the degree that nominalism and skepticism can be thematized in the Daoist context, they do not presuppose the primacy of the artificial and constructed that is distinctive of much contemporary thought. Early Daoist texts provide an alternative to the modern impasse between essentialism and constructivism if "dao" 道 (as way and, originally, verbal wayfaring and waymaking) can be articulated as the lived or performative enactment of the intrinsic value and life of the myriad things, of "sky and earth" or the natural world (tiandi 天地) as such and as a whole through which how and the way humans address and are addressed by them. Daoism epistemologically and ethically "saves the phenomena," potentially correcting the one-sidedness of anthropocentrism and biocentrism by attending to these things themselves-intrinsically and for their own sake rather than as objects reduced to value, use, and exchange-in the context of the self-cultivation or perfection (zhen 真) of life and reality. ${ }^{6}$

Many might question whether ancient "wisdom-literatures" can speak to us "moderns," who both benefit and suffer from our dominion over nature. In Dialectic of Enlightenment, a crucial work concerning the domination of nature, Theodor Adorno and Max Horkheimer argued that profits come with profound losses as the defacement of "external nature" (the natural world) is paid for with the mutilation of "internal nature" (the human world). ${ }^{7}$ It follows from their analysis that the concern with nature for its own sake, as more than a product of human concern and calculation, cannot be separated from questions of human welfare and happiness. In contrast to the binary either/or of biocentrism or anthropocentrism, environmental destruction intersects with issues of achieving human health, longevity, and wellbeing. Curative and preventive means of realizing such ends are accentuated in many Daoist traditions and by and large in Chinese culture, sometimes themselves causing destruction to the environment and biological life. One controversy about the ethical character of Daoism is whether it can be reduced to calculations and techniques of longevity and self-perfection reflecting in the end an anthropocentric and egotistical self-interest oblivious to plants and animals and the environment. I contend that it should not, since Daoist bio-spiritual practices (1) can be distinguished from those of macrobiotic hygiene in general Chinese culture ${ }^{8}$ and (2) should be situated in relation to dao and its unforced and incalculable naturalness (ziran 自然). 9

One assessment of the ecological value of Daoist traditions contends that only "modern Western approaches" can solve "modern Western problems." This contention is erroneous if environmental destruction is not exclusively "Western" but global, and not only a modern phenomenon but one of long standing. For Horkheimer and Adorno, the domination of nature under instrumental reason did not begin in modernity and with the enlightenment, as anti-modernists contend. It was already operative in ancient myth, just as myth persists after enlightenment. ${ }^{10}$ Nature 
is not only an issue for one privileged civilization or era. In different ways the environing world is a question for each historical way of life as a manner of existing in the world in relation with others and things.

Ancient Chinese sources already mention ecological damage. Zhuangzi mentions the utilitarian consumption of trees and animals, and Mengzi employs the deforestation and "using up" of Ox Mountain as an analogy for the demoralization of a person. ${ }^{11}$ Observed degradation associated with the growth of mass agriculture, deforestation, the control of rivers, overgrazing, and so on, which can be appropriately described as "environmental issues," are a point of departure for Daoist texts of the Warring States and Han dynasty periods. The claim that features of the environment and animal life inform early Daoist accounts of natural phenomena is not only historical but philosophical, seeing that these texts do not separate either the environing world from "nature as such" or the experienced natural world from the ontotheological duality of the divine and the natural. It follows that there might be at least an implicit environmental ethics or proto-ecology in passages in the Daodejing advocating a more receptive and reverent approach to the myriad things residing between sky and earth- "working with them and turning none away," and aiding "the ziran of the ten thousand things" without needing to do so or coercing them. ${ }^{12}$

Early Daoist cultivation (zhen) of the non-cultivated-of ziran 自然 (natural and spontaneous self-generating self-so-ness) and wuwei 無為 (effortless non-calculative responsiveness) - may be more salient to contemporary ecological thinking than frequently imagined. Daoism is not the deep ecological biocentrism that some represent it as - a claim that has its antecedent in Xunzi censuring Zhuangzi for forsaking the human in obsessively pursuing nature (tian)—given its inclusion of well-being, longevity, and bio-spiritual practices. ${ }^{13}$ Despite this inclusion, and the common value of achieving personal welfare in ancient China, early Daoism cannot be reduced to a self-interested concern for longevity or immortality. ${ }^{14}$ This is evident in the Inner Chapters - if not all the later ones-of the Zhuangzi, which praised naturally achieved longevity, although not expressed as an anxious concern over longevity, and advocated the acceptance of death (controversially including the death of Zhuangzi's spouse) as part of the unending transformation of things. ${ }^{15}$ Hence, rather than categorizing it as biocentric or anthropocentric, Daoism is better described as a naturalistic pluralism, intimating an alternative to the dominant discourses of anthropocentric monism prevalent in humanism and anthropomorphic religiosity, which both define things according to the priority of human existence.

Contemporary environmental thinking and activism recurrently exhibit the structures of domination and interventionism that they criticize in others. Environmentalists can also learn, then, from ziran and wuwei as practices that "support the myriad creatures in their natural condition" by opening the field in which one freely responds to things as such, that is, to the multiplicity of the myriad phenomena in their harmony and interdependence (dao 道) as well as in the diversity of their specific and concrete uniqueness (de 德). ${ }^{16}$ Such responsiveness is exemplified in the image of the ancient Daoist kings of the Yuan Dao in that "there was nothing to which they did not respond" and that they were "never at a loss in their response."17 
This listening and responding to the innumerable beings of this world constitutes an "ethics of things" that unfolds in the human context of self-cultivation without concern for self, merit, or name. Through a yielding responsiveness to each thing (whether human or inhuman) in its immanent self-generation (ziran), this ethics heeds our belongingness to the rhythms and transformations of beings and the world - which, although deeper than human knowledge and dominion, are irreducible to either arbitrary chaos or a fixed authoritarian and hierarchical order. ${ }^{18}$

The Daoism of longevity — of Ge Hong and alchemical traditions-is often construed as anthropocentric, self-interested, and oriented toward a spiritual transcendence that instrumentalizes the immanent natural world. Yet the emphasis on the harmonizing of natural immanence and spiritual transcendence in the Daodejing and the Zhuangzi undoes anthropocentrism and its anxieties by exhibiting both the restless discord and effortless accord between the human and the inhuman. This natural yet often unrealized accord, which is what Zhuangzi means by achieving the one, can be formulated into three interconnected insights drawn from the Zhuangzi. First, the intrinsic difference between beings in their situational self-so-ness or naturalness (ziran) entails contesting the fixated categories, according to which things are left unseen and unheard in being conventionally boxed and labeled, in order to respond to them freely in their uniqueness, singularity, and life. Second, the intimation of the natural parity and relative equality and interconnectedness of beings disrupts their hierarchical subordination and instrumentalization, according to which the world is carelessly divided between the categories of the useful and the useless. Third, recognizing the inherent and unending transformations of things, and their emergent transitional perspectives, undermines any synthesis of the first two claims in a third thesis that would eliminate either their plurality or parity. The occurrence and enactment of the ethical consists in both (1) the asymmetry of recognizing what is uniquely itself from out of itself-that is, the particularity of its own self-generation and perspective-and (2) the symmetry of engaging in the mutuality and parity of asymmetrical yet reciprocal relations. Although these three insights cannot be ranked, and are not a system of rules, they potentially reorient environmental thought even while pointing beyond it.

\section{The Difficulty of Speaking of Nature}

The Laozi and Zhuangzi do not speak of ecology, environmental ethics, or "nature" in its Western and modern senses. They can still be environmentally relevant if they address the phenomena in such a way as to reveal their unconsidered possibilities and promise. Despite early Daoism remaining a controversial and contested source of ecological thought, it provides a compelling model for thinking about environmental issues based on its understanding of (1) the natural world and (2) the appropriate self-cultivation of the zhiren 至人 (perfected person), the shenren 神人 (spiritlike person), and the zhenren 真人 (realized, actualized, or cultivated person), which are different terms for the one who cultivates life or reality itself as more than artificial and conventional social life. ${ }^{19}$ Words such as shen 神 (spirit) and jing 精 (form or 
essence) in the Zhuangzi can also be understood in relation to the zhenren as the disposition and attunement of a self receptive to, yet not afflicted by, the world.

The Zhuangzian self diverges from the $r u$ 儒 or Confucian elucidation of the human self through xing 性 (nature, usually inborn or human nature). It does not require the constancy of an internal nature or essence that developmentally unfolds itself as conditions permit, being a disposition or comportment freely answering the world and, in answering, transforming itself in accordance with it, thereby remaining itself. $R u$ and Daoist traditions both stress the significance of cultivating the self. Yet whereas $r u$ traditions generally construe cultivation as the hierarchically organized social education, molding, and shaping of a preestablished and inborn nature, whether good or bad, early Daoism approaches the natural world as a fluid and transformative reality reflecting the changing capacity, disposition, and comportment of singular beings vis-à-vis their world. ${ }^{20}$ Realized or unrealized in relation to things, nature is not a teleological realization of potentiality with a fixed trajectory and end. In early Daoism, the way is not teleologically defined by an external goal but by the traveling of it. This wayfaring itself forms the way, and the way is not independent of its journeying. Daoist being-underway is not aimless or purposeless in the sense of meaningless. Resonating with the freedom of Kant's Critique of Judgment, it is purposiveness without a predetermined purpose. Self-cultivation is an unforced turning toward the unfolding naturalness of the world and of oneself as a responsive, unforced, spontaneous attunement with it. ${ }^{21}$ Early Daoism accentuates the primacy and primordiality of the way (dao) and sky and earth (tiandi) in relation to which the human occurs, and it is from this nexus that it articulates the capacities and dispositions of "human nature."

Basic words such as dao, tian, di, tiandi, and xing are difficult to translate, as they correspond and overlap in some ways while resisting in others Western ideas of "nature" originating in the Greco-Roman and Judeo-Christian experiences of life. The Roman understanding of natura implies the raw stuff or material of cultivation, formation, and production. The later standard Christian interpretation defines nature as a finite and limited product of an infinite and unlimited being. More debatable are the Platonic and Gnostic tendencies depicting the transitory as meaningless. According to Plato, what perishes never really existed, and in Gnosticism immanent nature is intrinsically wicked, fallen, and depraved, such that it can only be redeemed from outside itself from a transcendent source assigning it its significance and value.

The dominant Western conception of "nature," as an inherently extrinsic and derivative realm dependent on divine and human production, construction, and calculation, is fundamentally inadequate to the holism and "singularism" at play in the language and experience of dao, in which each thing and moment discloses itself as self-generating and intrinsically meaningful in and of itself. If each thing has its own norm or rule and this is its nature, ${ }^{22}$ then the singularity and intersecting nexus of things is not merely derivative. Approaching nature as ziran, the self-so-ness of a thing, is an ethical rather than a speculative claim in that it opens up different possibilities for encountering things, even if the life and promise of things is habitually taken for granted and left unanswered in both East and West. ${ }^{23}$ Jordan Paper's asser- 
tion that the philosophy of nature is irrelevant to environmental ethics is dubious, given its problematic categorization of the useful and useless, and if the way in which the world is encountered has ethical implications for how one relates and fails to relate to it and to things. ${ }^{24}$ However, it is not the "metaphysics of nature" that is so much at stake as it is an "ethics of encounter" that does not exclude or trivialize the nonhuman.

Questions of translation and language are inescapable in explicating the ethical import of early Daoism. Not only is the difficulty caused by the enormous differences between English and classical Chinese; it is heightened by Daoist ways of speaking. Language can be more than the propositional representation, or the subsuming of particulars under universal concepts; it can speak otherwise by proceeding from the concrete particularity of the phenomenon itself. ${ }^{25}$ The Daodejing and the Zhuangzi make multiple and indirect uses of such concrete "pictorial thinking" as well as of apophantic, aporetic, and paradoxical ways of speaking, which are not ornamental but constitutive of the sense and effect of their language. This playful communication transcends propositional content in being primarily performative, and calls on listeners and readers to enact what is said in their own ways. Dao, as paradoxically naming the unnamable and nameless (wuming 無名), does not function as another name, universal, or concept. Dao does not signify an objective essence or entity; it is not even a signifier in the ordinary sense. ${ }^{26}$ As Youru Wang has argued, dao is the absence of signifiers, ${ }^{27}$ receiving its significance by being an unnamable way that cannot be propositionally spoken about but only lived, followed, and enacted: "Those on the way need to become the way." 28 Daoist language is evocative of a way fulfilled by the listener, involving saying and unsaying, and it misses the point to linger in the propositionally said statement.

It is insufficient, then, to read texts like the Daodejing from a third-person perspective, seeking information and propositional content about things. It calls for a hermeneutics of "responsive participation" in relation to the text and the world, which Ames and Hall have elucidated as a creative mirroring response to the other on its own unique terms. ${ }^{29}$ This interpretive strategy has the advantage of connecting two of the primary senses of ziran-as (1) an anarchic yet not arbitrary spontaneity and as (2) the intrinsic uniqueness or "self-so-ness" — through responsiveness. ${ }^{30}$ This intimates, in the language of Ames and Hall, linking the oneness and interdependence of beings (dao as field) with the singularity and uniqueness of things (de as focus). In their interpretation, the primary metaphor governing this connection is not the biological organism but the family. Ancient Chinese cosmologies, Daoist and Confucian, comprehend all relations_including natural ones-as familial. The person is inherently constituted in a web of relations in which she has a unique place and position. Yet whereas the primary familial metaphor of $r u$ thought is the father and his filial son, the image of the feminine, the mother, and the child take precedence in early Daoism. ${ }^{31}$ The Daodejing's language does not instantiate a universal; it enacts and performs a configuration of familial/natural relations.

This line of reasoning clarifies the repeated appeals in the Daodejing to become wise by performatively and dynamically becoming like the feminine, the maternal, 
or the childlike 32 -images also found in the Zhuangzi-that is, to be receptive and affirming, creative and fecund, and natural, playful, and spontaneous. Something like this playful and creative receptiveness, or the responsive spontaneity of language and action, is found in the later Daoist "inner alchemy" (nei dan 內丹) traditions-which use an intricate alchemical language to describe meditative transformation-that speak of a dynamic process in which all things creatively participate and of the openness in which creativity and receptivity are joined together. ${ }^{33}$

\section{In Praise of the Useless}

"Everyone knows the usefulness of the useful but no one knows the usefulness of the useless." 34 Several anecdotes from the Zhuangzi advocate rejecting the anxieties of power and fame, praising "non-power" and the apparently "useless" and "deformed." The useless (or nonfunctional) and the misshapen (or dysfunctional) are usually and for the most part barely acknowledged by the conventional order until they disturb it and the popular premise of pragmatic calculation that usefulness is the ultimate criterion of the things. ${ }^{35}$ The fixation on usefulness is not useful by undermining the possibility of being open toward and appropriately responding to the myriad things. In much Eastern and Western thinking and practice, the innumerable things of this world often remain silent and unseen, becoming meaningless in being instrumentally reduced to values and schemes extrinsic to them.

In addition to the interruptive role of the useless, deformed, and counterpurposive in the Zhuangzi, which provides a broader context for the story of Cook Ding, other Daoist texts suggest a more humble and responsible alternative wherein humans tentatively draw on the generosity of heaven and earth without believing they can master and possess it. ${ }^{36}$ The Liezi accordingly states: "Your body does not belong to you; its form was lent to you by heaven and earth. Your life does not belong to you; it came into existence with the interactions of the energies of heaven and earth. Your mind and your spirit are not yours to control; they follow the natural way of heaven and earth...."37

Russell Kirkland has also discussed the dynamic natural realities and "salutary forces that humans did not create and cannot control" in the Laozi and Zhuangzi. ${ }^{38}$ These works call attention to the spontaneity and power of the natural as opposed to the normativity of human artifice and convention, taking "its measure from the things themselves" without submitting to any norm. ${ }^{39}$ The "power" of Daoist nature, and hence the self-cultivation of naturalness, contests and undermines power understood as mastery. This self-generative power, as de, should not be conflated with power as domination or external imposition, given that dao engenders without appropriation and molds without mastery. ${ }^{40}$ Daoism "naturalistically" contradicts constructivism, whether socially or idealistically understood, and without reducing selfgenerating nature to the biologistic and pseudo-Darwinian self-assertion and mastery of the "struggle for existence." I would go further than Kirkland in arguing that this non-reductive and responsive naturalism, in which humans recognize their belonging to a wider context of existence, already indicates a philosophical point of depar- 
ture for environmental ethics even if Daoism should not be reduced to environmentalism and especially the utility of application and engagement criticized in chapters 4 and 6 of the Zhuangzi.

\section{Cruelty to Straw Dogs}

Yet isn't the natural world only the brutal violence and uncultivated barbarism of being that needs the controlling hand of human culture and rationality? Doesn't the recognition of natural forces demand sacrificing the human and humane? One objection to early Daoism is that it demands the sacrifice of the human to nature in the name of "the Dao," and of the people for the sake of the sage. This objection is based on the Daodejing's reference in chapter 5 to straw dogs (chu gou 㫚狗): "Heaven and Earth are not benevolent; They treat the myriad creatures as straw dogs. Sages are not benevolent; they treat the people as straw dogs." 41 Whereas some passages of the Daodejing are criticized for apparently promoting immoral impartiality and neutrality, as when Laozi speaks of going beyond good and evil and treating the just and the unjust alike, other sections advise overcoming conventional moral discrimination in order to be equally responsive-and therefore ethical-to each and all.

While some commentators praise or denounce this passage as a kind of universal indifference, "straw dogs" needs to be understood in the context of pre-Han Chinese religious practices. In the post-Han (possibly third century) work Xiang'er Commentary on the Laozi, the first Celestial Master (Tianshi Dao 天師道) commentary on the Daodejing, "straw dogs" are understood to be mere sacrificial scapegoats, and chapter 5 is read-contrary to what the text explicitly states-as advocating being humane to the good and inhumane to the bad. ${ }^{42}$ Although the first part of this interpretation has become conventional, it seems more apposite to interpret chapter 5 in relation to chapter 14 of the Zhuangzi. First, these two texts are closer both temporally and philosophically. Second, they use the metaphor of a straw dog to refer to responding to things in their temporal and transformative character. In both texts, the sage is not tied down by the partiality and gradation of Confucian benevolence (ren 仁), treating things alike or equally without special preference or anxious attachment. Without mourning and nostalgia, the sage appropriately responds to the myriad things as they come and go, as they are born and cease to exist, just like the $q i$ 氣 (vital energy) that gathers in sacrificial straw dogs and empty vessels and is then dispersed.

The reference to straw dogs does not point to an apathetic and cruel willingness to sacrifice others to fire, as some commentators erroneously argue. That interpretation presupposes a different and anachronistic construal of the religious ceremonies in which qi was gathered in a straw animal or an empty vessel. Once a rite was completed, the vessels or straw forms were destroyed or purified so that the forces of $q i$ did not remain trapped and become harmful. This meaning is alluded to in chapter 14 of the Zhuangzi, when Shi Jin speaks of a straw dog in an analogy indicating that the past cannot be preserved. Anyone who tries to retain or reuse a straw dog is dis- 
turbed by nightmares, according to this passage, just as the Confucian is haunted by the dead he reveres. Letting straw dogs lie is an analogy for rejecting traditionalism, the conventional yearning for the lost past. Rather than being disrespectful and cruel to "straw dogs," which is the image of each of us, these passages exemplify recognition of and responsiveness to the thing in its own moment or temporal appearance.

Sima Tan described temporality, responsiveness, and appropriateness as the primary features of daojia when he stated that it shifts with the times, changing in response to things, appropriately establishing apt customs and practical applications. Such responsiveness, as appropriateness to the temporal character or seasonality of the passing by of innumerable natural things, ${ }^{43}$ should not be reified into a fixed and dead answer. Any self-transforming thing calls forth changing responses, and neither language nor humans and heaven are fixed in the Zhuangzi. ${ }^{44}$ These sections imply that nature as a whole (dao) is bound to the singular and unique (de), just as the sage reveres human life as it has its moment and passes away. The sage respects the singular in its fleeting yet singular moment, rejecting institutionalized and conventional "benevolence" (ren), not due to immorality or indifference-as critics contend, since early Daoism embraces natural compassion ( $c i$ 慈 $)^{45}$ —but due to a naturalistic ethic of responsive spontaneity. In the Yuan Dao there is no hidden deeper reason behind the things themselves in their suchness or self-so-ness. Responding to the naturalness of the plurality of things contrasts with how the intellect tends to reify things. By interrupting the socially constructed and administrated self, responsiveness to things is the condition of returning to the self. ${ }^{46}$

This ethics of naturalness is related to, yet distinct from, ancient Chinese ethicocosmological ideas about heaven and earth rewarding morality and punishing immorality, in constructs such as the Mandate of Heaven. In Han Daoist texts like the Huainanzi, heaven, earth, and humanity (tian-di-ren 天地人) are understood as a triad - either in harmony or disharmony - such that the violence of nature occurs in response to human activity that has disturbed the balance and flow of things. Later Daoist texts recount the destructive power of nature as a consequence of human activity and as a kind of return or revenge of the oppressed and forgotten. In the Zhuangzi, relating to things in their own timeliness and temporality is not a cosmological or metaphysical claim but an ethical one about one's way or mode of living. This pre-theoretical ethics calls one, prior to calculative concern, to acknowledge and respect the temporal rhythms and mutuality of life and death without evasion and fear. Temporality and finitude are not derivative or "fallen" characteristics that negatively afflict human life but are constitutive of that life-whether acknowledged or not.

Because it places the human world in the natural world, immanently and naturalistically "hiding the world in the world," some critics of Daoism fear that it potentially romanticizes the natural world as idyllic and reactively venerates it for its irrational and merciless power and potency. Yet Daoist naturalism entails something different than such caricatures of "romanticism" that anthropomorphically project human feelings onto nature. As opposed to the richness and diversity of European romanticism and idealism in their historical contexts, which have often had politi- 
cally progressive tendencies, such a one-dimensional and reactionary "return to nature," in the ideological form of worshiping nature as a blind power of destiny justifying the subordination of other humans rather than their recognition, occurs as a blind self-assertion of power that reduces the generativity and fecundity of nature to the anxiety and unease of the conatus and its struggle for existence and self-preservation. In National Socialism, the seeming celebration of nature-in the mountains, rivers, and forests of the homeland-degenerated through the racialized biologism of blood and land into the anthropocentric self-deification of capricious human power as natural, which did not disrupt but intensified the subjugation of nature and other humans. ${ }^{47}$ Yet the justified rejection of ideologically distorted affirmations of nature ought not to excuse the domination of nature. Daoism does not call us to worship nature as a Divine Other, a blind irrational power, or pantheistically as our own self. Containing critical and skeptical moments in the face of such reification, it indicates a transformed relation to life in which the human-potentially dwelling and wandering free and at ease (xiao yao you 逍遙遊)—overcomes the hubris of destructively setting itself apart from the nexus of its existence. ${ }^{48}$

\section{Toward an Early Daoist Ethics}

The return of Laozi and Zhuangzi to dao as something older than the oldest yet still the most youthful, and more originary yet still the most derived, is a turn toward the phenomena themselves rather than a source or origin separate from them. As the highest and the most humble, it challenges the activism and self-aggrandizement that tempts the subject. To the extent that environmentalism is another way of asserting the power and dominance of the human subject, such moralizing mastery potentially undermines its own goal of preserving the environment from destruction. According to this account of Laozi and Zhuangzi, it is the activity of the subject that is the source of the problem and, as such, it cannot be cured by another-however different and "well-intended" — activity of that subject. If it does not recognize responsive letting, the non-power and non-usefulness of things, a recognition transforming the human relationship to its nonhuman contexts, environmentalism risks undermining itself.

Laozi and Zhuangzi evoke how to accept or be responsive toward nature through the practice of free and effortless "non-coercive activity" (wuwei), which is at times misinterpreted as mere mysticism and fatalism, as giving up and doing nothing to change things. Russell Kirkland, in his essay in Daoism and Ecology, explains the many ways in which classical Daoists were not environmentalists, humanists, or do-gooders. ${ }^{49}$ However, the Daodejing and Zhuangzi reject ethical theorizing, calculation, and anxiety rather than ethical behavior as such, given that they invoke ways of life involving receptivity and compassion (ci), simplicity, and sincerityterms having an existential ethical import. A work criticizing the exploitation and oppression of people by their rulers, the decay of ethical responsiveness into an adverse bureaucratic morality, and the unforgiving consequences of war and violence is not suitably described as unethical and nihilistic. ${ }^{50}$ Likewise, the Zhuangzi cri- 
tiques making knowledge and the ethical instrumental and discursive by extending them beyond ourselves and violating others.

The contention that early Daoism ethically cultivates the self in the context of life is reinforced by its criticisms of conventional and codified morality. It ethically interrupts such moralities in rejecting the reification and degradation of ethics into arbitrary rules, static hierarchical relations of subordination, and unresponsive rituals. Such social phenomena are a fundamental loss of worldly attunement and responsiveness and of the non-hierarchical and reversible relationality that prediscursively and pre-cognitively constitutes ethical immediacy. The conventionalization and institutionalization of the ethical into codes, rules, and virtues, and its reduction to dualistic categories of good and evil signifies the loss of something more basic and a growing injustice in the Daodejing (chapters 18-19) and the Zhuangzi (chapters 10-11). Ethical benevolence and righteousness, with its calculating judgments and rationalizations that punish the weak and unfortunate while rewarding the robbers of state, is not the realization but the eclipse of the ethical. This selfdevaluation of values is set in motion by the establishment of fixed functions and principles, which do not follow the transformation of things, such that the person no longer knows what is to be valued or how to value. Early Daoism does not deny dao and community but-in an ancient antecedent to genealogical "ideology critique" - their manipulative uses: "only when dao is lost do benevolence and righteousness appear, only when the nation is disordered do patriots spring forth." 51

Kirkland contends that Daoism aims at spiritual enlightenment and is indifferent to the suffering that is part of nature, thus eschewing the humanitarian and heroic intervention demanded by environmental activism. His conclusion that the nonactivity of wuwei calls for passive worldly indifference is inaccurate if: (1) dependence and passivity are ethical, as anarchic responsiveness in contrast to hierarchical subordination, and (2) non-attachment and non-coercive activity are the condition rather than the denial of genuine compassion. Some detractors deny the role of compassionate responsiveness in Daoism, ignoring the references to and role of $\mathrm{ci}$ (compassion) in the texts, not to mention the important ethical dimension at work in various ways in all Daoist lineages. ${ }^{52}$ The Daodejing and the Zhuangzi are not indifferent to the destructiveness of war, poverty, famine, and social oppression, since these are rejected in developing the effortless responsiveness (wuwei) and care (ci) achieved through cultivating life and reality (zhen).

The "wu" 無 words, in which wu is usually translated as "non-" or "in-," do not denote a general indeterminate negation that entails indifferent inactivity. Ames and Hall translate, for instance, wuwei as "non-coercive action" instead of "nonactivity" to highlight its receptive and responsive character. ${ }^{53}$ Similarly wuyu 無欲 does not imply the indeterminate negation and repression of desire but "the achievement of deferential desire." 54 Wuzhi 無知 does not mean embracing ignorance, understood as uncaring stupidity or forcing this onto the people; it is an anarchic and "unprincipled knowing" involving receptive and responsive mirroring. The kind of knowledge ( $z h i$ 知) denied in wuzhi fails to realize its intention of achieving sage-like wisdom and is genealogically diagnosed as the growing absence of dao. ${ }^{55}$ Chapter 3 has been read as justifying the oppression of the people through eliminat- 
ing their knowledge and desire for the sake of maintaining the ruler's control. ${ }^{56}$ This is incongruent with the emphasis on non-coercive and compassionate action seen elsewhere in the text. It can be read as a legalist interpolation or misreading, insofar as the denial of knowledge (wuyu) and desire (wuzhi) is their liberation in anarchic knowing (wuzhi) and objectless or deferential desire (wuyu), which is achieved not through coercive violence but through the non-coercive receptivity of wuwei.

As receptive, the "passivity" of wuwei does not entail unresponsive and uncaring indifference and neutrality. Yet this non-indifference does not depend on conventional moral rules and virtues. Insofar as there is ethical-political criticism in these texts, and therefore a Daoist ethics, as argued here, it is not based on conventionalizing dao as a universal norm or principle that is then secondarily "engaged" and "applied" to phenomena. It is a "norm" immanent to the concrete and particular occurrence of the myriad things themselves, as in the example of Cook Ding or when, for Zhuangzi, "the flat level surface of still water provided the model for the carpenter's level." 57 Early Daoist ethics can be seen as proceeding through (1) what might be described as a "genealogical immanent criticism" of "small," one-sided and destructive views, practices, and institutions, exposing the artifices of a socialized "second nature" that mistakes itself as nature itself, and (2) the itinerant performative enactment of naturalness in the self-cultivation of one's immediate ethical disposition and comportment toward things.

\section{Force and Counterforce}

Daoism's critics, beginning with the ru tradition, maintain that it is unethical, irresponsible, and antisocial. Examining Daoist traditions makes it clear that Daoism provides significant insights for engaging ethical and social issues, precisely because it does not proceed exclusively from human intersubjectivity - whether interpreted as egalitarian or hierarchical-but from the intersection and openness of the human dwelling and wandering between earth and sky. Instead of ethical and social life being based on the domination of nature, in which it is transformed into an instrumental object of calculation and control, Daoism discloses an alternative relation between the human and the natural on which it depends and to which it belongs. Just as dao nourishes by not forcing, by not dominating, the Daodejing suggests that the ruler rules best without force and violence. Nature and society are not divided into unconnected opposites, and their mutuality implies that harming one equally harms the other. This reading is supported by the contrast in the Yuan Dao between relying on dao and relying on devices, and between the beneficent heart and the calculating heart. ${ }^{58}$ Whereas the Daoist sage-king of old attained integrity and self-knowledge, and the world responds accordingly, the reliance on force and calculation seals the legalist's fate. ${ }^{59}$

The transmitted text of the Laozi includes some statements that reject domination and others that apparently support it, yet the latter "legalist" propositions are not found in all collections of the Laozi material and seem to be historically later. ${ }^{60}$ These legalist directives about how to manipulate and control the masses are not more significant than other more prominent tendencies in the text, placing such cal- 
culation and planning into question. A number of passages are at odds with and contradict legalist control and manipulation and advocate nonlegalist virtues such as unforced and unprompted compassion. ${ }^{61}$ According to chapter 30 of the Daodejing, force persistently creates its own resistance and diminishes the capacity of the one who exerts force to continue to exercise it. This suggests the reversal (fan 反), interpreted as transversal below, of power and control through non-activity in opposition to its coercive reproduction and maintenance. The movement of reversal at work in the Daodejing intimates some facets of the dialectic of enlightenment diagnosed in Adorno and Horkheimer, specifically the connection between the domination of external nature with the domination of internal nature. The Yuan Dao ties together preserving and balancing "outer" and "inner" nature, the natural and human worlds, in a number of proto-ecological passages encouraging-according to the interminable dialectic of yin 陰 and yang 陽—respect for the basic nature and environmental circumstances of things. ${ }^{62}$ Early Daoism is responsible in being responsive to things, and is consequently not irresponsible in calling the ordinary model of accountability, reward, and punishment into doubt, and in placing authoritarian and dominating forms of human activity and mastery into question.

The Laozi, Zhuangzi, and Yuan Dao draw out the ineffable or unsayable quality of dao ("dao that can be named is not dao") not for the sake of aesthetic nihilism and moral indifference but in order to address and be addressed by the myriad things. Accordingly, in the Yuan Dao, emptying the heart is not neutral apathy. It is the condition of responding to things such that the one with dao is described as capable of appropriately and fittingly responding to things in the opportune moment without anticipation or calculation. ${ }^{63}$ In this responsiveness, transcending the socially defined and limited responsibility of the conventional self defined by customary common life, an alternative to the ongoing destruction of earth, water, and sky by human activity is revealed. Instead of being "anti-humanistic" in rejecting the centrality of the socially defined human ego of "Confucian humanism," early Daoist sources display - in the light of wuwei as non-coercive activity - a more elemental humanism in which the human is itself in its responsive attunement with the fluidity of natural processes. This belonging to and dependence on things does not mean being limited and confined by them. As responding and moving in relation to them, it is not being commanded, overpowered or subjugated by them. Dao only transpires in unforced and free listening. ${ }^{64}$ In hearing dao, one spontaneously and immediately embodies it. "Responding with dao" does not imply coercive obedience to a mysterious external substance or law called "the Dao." On the contrary, it is "living dao," generating the way in wandering it, and its own uncontrived performative self-enactment.

\section{The Ethics of Nature}

Ziran in the Zhuangzi is a double immanent movement consisting of both responsiveness to nature and the spontaneity of nature. Whereas other classical Chinese thinkers argued for morally perfecting the human condition, according to contradic- 
tory ideals of the goodness and evilness of human nature and the proper standards of moral judgment, Zhuangzi illustrated their inadequacy and the possibility of humans living according to dao by letting things naturally be themselves, each in their own way according to their own course and nature, instead of violating them by the overextension and ensuing self-ruination of human nature. Insofar as the myriad things occur through themselves and intrinsically for their own sake, acting against things by treating them as products of human calculation and control is inappropriate. ${ }^{65}$ Contrary to the self-destructive obsession with profit, morality (whether good or evil), and utility, humans need to recognize how they relate to nature from within nature itself.

The capacity of humans to master things and govern people is questioned in the Zhuangzi. Incapable of saving themselves through their own isolating activities and projects, humans mutilate themselves through the violence they inflict on things. Reducing the infinite variety and variability of the world to the simulated order of usefulness and purposiveness, human life is haunted and undermined by the useless, the non-intentional, and counter-purposive, which are the results of its own categories and practices. Zhuangzi concluded from this that one could do the most by "doing nothing" (wuwei) and undoing the categories and values that erroneously seem basic to human existence. Since only wuwei responsively mirrors and attends to the immanent spontaneity of nature, the minimalism of "doing less" interrupts the maximalism of incessant intervention, production, and consumption. Such balancing and restorative minimalism also indicates why it might be easier to wander free and at ease by foot than in an SUV, since the advertised freedom of the latter presupposes a world of bondage. Lisa Raphals has argued that wuwei is the self-cultivation of an indirect and humble kind of activity. ${ }^{66}$ Instead of interpreting it as arbitrary or an inactive and indifferent neutrality, she and others have ascertained the ecological potential of Daoist wuwei by disclosing its significance as a non-assertive and deferential activity. If our ecological plight is due to the irresponsible assertion of human independence from and mastery over nature, including the implicit ascendancy of this paradigm within environmentalist activism, then Daoist insights into the hubris of separation and assertion are not crippling but salutary.

Zhuangzi's naturalistic ethics and ethical naturalism are apparent in the Inner Chapters. Each of the ten thousand or myriad things has a life and perspective of its own; each is "singular" in being naturally distinct from every other. This singularity and inherent worth in each thing entails a relative parity to the extent that each is equally important in having its own life and way. The assertion of the relative parity and equality between things is not a denial of intrinsic difference and individuality in the Zhuangzi; it is based on it. For Zhuangzi, one equalizes through sorting and sorts through equalizing ( $q i w u$ 齊物). The deer, the centipede, and the tree live in a way that is different from the way I do, each within in its own scope, perspective, and configuration of forces. As each is relatively equal in being differently its own, one cannot not properly assert that one way of being is preeminent over others. The "great" perspective in contrast to the "small" recognizes its own limits, the finitude of its own nature, knowledge, and activity, no matter how great it might be, and the 
difference and equality of each thing. It is in this sense of proportioning and sorting while equalizing that all is one and alike in dao, and each singular being is potentially in accord with and complete in itself. By linking oneness and interdependence with the singularity and uniqueness of beings, Zhuangzi does not lead us into the dichotomy between a systematic totality that imposes itself externally upon things and the sovereign yet abstract and isolated monadic individual of Western metaphysics. ${ }^{67}$

The natural world operates spontaneously, fluidly, and through alteration, selfgeneratively transforming itself according to its own flows, rhythms, and seasons. It has its own cadences and timeliness that cannot be fixed according to a predetermined principle or origin that the Zhuangzi stresses we cannot know. Running through the theses of the intrinsic difference and relative parity of the innumerable things is this third thesis of the naturalness of becoming, transition, and transformation. This self-transformation of nature involves the concrete mutuality of things such that a person can dream of being a butterfly, life is inherently tied to death, the seemingly monstrous and misshapen most manifestly live the dao, and the masculine finds dao only by recourse to the feminine.

\section{Transversing Gender and Nature}

Joanne Birdwhistell argues that Daoist ecology and biocentric deep ecology are problematic in remaining tied to male structures of domination and oppression. She maintains that the structural similarities of Daoism to deep ecology, including employing the feminine as a secondary term denoting the natural, bear out its inappropriateness for contemporary thought. ${ }^{68}$ Daoism's ecological potential can be maintained if Birdwhistell's arguments inadequately (1) distinguish patriarchal and hierarchical universalism, which she attributes to Daoism, from a pluralistic holism that throws all hierarchies, patriarchy included, into question; (2) develop the dialectical significance of reversal as unending transversal without a terminating synthesis; and (3) articulate the responsiveness of Daoist yielding and "passivity" as something different from blind subservience to authority and fate.

There are several reasons to distinguish "the whole" interpreted as a hierarchical universalizing system and assimilative totality, relentlessly subsuming particulars under universal governing laws, from "the whole" as a contextual nexus and interdependent relationality of singulars. ${ }^{69}$ Other readings of the Daodejing reinforce the previous arguments in this essay that the holism implied by dao is balanced by the particularity of de. In Karyn Lai's analysis, respecting de entails that the individual cannot simply be sacrificed for the whole. ${ }^{70}$ Roger Ames and David Hall suggest that the holism of the Daodejing is one of singularity in contextuality or the dynamic interconnectedness of particulars. ${ }^{71}$ For Brook Ziporyn, the Zhuangzi does not employ a "unicentric holism" that subordinates the particulars to a universal principle or systematic totality but is a variety of "omnicentric holism," meaning that the whole is not ordered from one privileged center, or absolute universal point, to the extent that each particular point in any whole is itself a center. ${ }^{72}$ 
Without one static organizing center, motility and reversibility exemplify dao: "reversal is the dao's movement." 73 This reversibility does not conclude with the initial reversal, even if reversal (fan) indicates a return to the root, nature, or the origin. ${ }^{74}$ All reversal is itself further reversible, as the source returns to and moves toward itself repeatedly without finality or a concluding synthesis. That is, all return can itself be turned, such that Daoist logic disrupts the potential reification of reversal and revolution as well as the institutionalization of new hierarchies. This dialectic of non-identity, in its movement between particular and whole and its play between concept and thing, interrupts the subordination and reified affirmation of the supposedly "lesser term," such as the "feminine," since that term itself can be further reversed, and the mutuality of opposites means that reversal can be infinitely transversed. By emphasizing unforced natural harmonies in opposition to forced unification, this dialectic can disturb hierarchical subordination and imposed identities.

Robin Wang has shown how in some noteworthy tendencies in Daoist and ru thought, the dialectic of yin and yang is neither a purely conceptual nor a material logic. ${ }^{75}$ It is better described as a "self-generative" logic of things, which is inherently naturalistic and "environmental" in its implications. Instead of a mechanical back and forth between the duality of thesis and antithesis, there is the generativity and fecundity of an infinitely plural variation. Water is a powerful Daoist root image for the generative processes of life evoking fullness and fluidity, inexhaustibility and responsiveness. ${ }^{76}$ Water in Chinese antiquity is not merely a symbol of the infinity of the transcendent; it is the source and character of life itself. ${ }^{77}$

If the role of the feminine in Daoism can be explicated along these lines, it is justifiable to speak of traces and fragments in early Daoism that address contemporary feminism and eco-feminism. As Karyn Lai accentuates, it is not so much the position of women and the feminine-given the social status of women and the values, such as submissiveness, associated with the feminine in ancient China-that poses problems for feminist scholarship, but the complementary character and differentiated mutuality of contrasting pairs allowing masculinity and femininity to be articulated in their identity and difference. ${ }^{78}$ Affirming what lies beyond duality through the terms that constitute the duality (yin and yang, heaven and earth, male and female), as distinct from hierarchically reifying the dominant (the primacy of heaven, the masculine, etc.) and lesser terms (earth and the feminine), early Daoist logic places in question the reasoning behind prioritizing one term of the dialectic. It proceeds instead through duality to its displacement via the affirmation and transversal of the supposedly "lesser" term, a movement that does not abandon it.

Daoism takes recourse in the feminine without necessarily instrumentalizing and subordinating it in a new hierarchy, as much as early Daoist strategies undermine the formation of hierarchies that undermine the difference and parity of things by conflating social-cultural constructions with nature itself. The Daoist dialectic of non-identity and de-reification challenges the subordination of women by opening up the possibility of responsiveness to each woman in the particularity of her existence as something other and more than the conventional social categories. This would not take place without undoing the forces that in different ways keep women, 
other humans, and things under control, degraded, impoverished, and in abjection. Daoist engagement for the "lesser term," defined as "lesser" by prevailing social conventions that are mistakenly taken as the natural order, was often-as shown by Sarah Allen-quite provocative in challenging dominant values and entrenched practices. Laozi commends the lower reaches of rivers, for instance, where the Confucian gentlemen only saw "swamps" and gathering pools of "detritus."79 As opposed to "romantically dreaming" of saving the constructed ideal of "idyllic nature" at its most beautiful and sublime, as critics discussed above have charged, this example illustrates the prospect of engaging things on their own terms even when they seem to be at their most abject, degraded, and worthless. This is an inherently ethical challenge with continuing relevance for how humans relate and fail to relate to others, things, and their environing world.

Notes

I thank Terre Fisher, Franklin Perkins, and two blind reviewers for their comments and questions that have helped to improve this essay, which takes up points from and responds to criticisms of my earlier essay, "Responding to Heaven and Earth: Daoism, Heidegger and Ecology," in Environmental Philosophy 1 (2) (Fall 2004): 65-74.

1 - N. J. Girardot, James Miller, and Liu Xiaogan, eds., Daoism and Ecology: Ways within a Cosmic Landscape (Cambridge, MA: Harvard University Press, 2001), includes a number of essays critical of the possibility of a Daoist-oriented environmentalism. Jordan Paper criticizes what he portrays as the faddish use and misinterpretation of Daoist texts in ecological thinking, suggesting that we need to reject "romantic fantasies" about Daoism in favor of a more informed perspective that interprets Daoism in relation to its Chinese context. He concludes that we can learn more ecologically from Chinese rituals based on the pragmatic character of Chinese traditions as a whole and the rujia tradition in particular than from Daoism (pp. 3-21).

2 - Daodejing passages are cited from the following translations: Roger Ames and David Hall, Daodejing: Making this Life Significant (New York: Ballantine, 2003); Philip J. Ivanhoe, The Daodejing of Laozi (Indianapolis: Hackett, 2002); and/or Stephen Addiss and Stanley Lombardo, Tao Te Ching (Indianapolis: Hackett, 1993). "Ddj" refers to the traditional section numbers of the Daodejing, whereas "Ames and Hall" plus page number refers to their introduction to or commentary on the text. I cite the Zhuangzi by chapter. I have consulted the Library of Chinese Classics Chinese-English edition of the Zhuangzi by Wang Rongpei, Qin Xuqing, and Sun Yongchang (China: Hunan People's Publishing House and Foreign Language Press, 1999), as well as Burton Watson's The Complete Works of Chuang Tzu (New York: Columbia University Press, 1968); Martin Palmer's The Book of Chuang Tzu (London: Penguin/Arkana, 
1996); A. C. Graham's Chuang-Tzu: The Inner Chapters (Indianapolis: Hackett, 2001); and Hyun Höchsmann and Yang Guorang, Zhuangzi (New York: Pearson Longman, 2007).

3 - In focusing on the Laozi and the Zhuangzi, I do not intend to perpetuate the separation of "philosophical" from "religious" Daoism, although the current reaction against this artificial division should not lead to devaluing the importance of the Zhuangzi in Han and post-Han Daoism. Zhuangzi was so influential on movements such as xuanxue 玄學 (“Dark Learning”) that Ge Hong 葛洪 felt compelled in the Inner Chapters (Neipian 內篇) of the Baopuzi 抱朴子 to mock Zhuangzi's naturalistic emphasis on fearless equanimity in the face of death while at the same time appropriating him as an exemplar for his own discourse of longevity and immortality, which requires that death be something to fear and avoid. Compare Isabelle Robinet's discussion of the connections between the two Daoisms in Taoism: Growth of a Religion. trans. Phyllis Brooks (Stanford: Stanford University Press, 1997), pp. 34-35, and Robert Ford Campany's discussion of Ge Hong's ambivalence toward Zhuangzi's naturalism in his To Live as Long as Heaven and Earth (Berkeley: University of California Press, 2002), pp. 84-85.

4 - The idea of a "Lao-Zhuang Daoist school" (Laozhuang daojia) developed in the Han dynasty, perhaps becoming an explicit designation as late as the Wei and Jin dynasties, according to Harold Roth, in his Original Tao: Inward Training (Nei-yeh) and the Foundations of Taoist Mysticism (New York: Columbia University Press, 1999), p. 6. Russell Kirkland rejects the existence of such a school as a basis for defining Daoism in Taoism: The Enduring Tradition (London: Routledge, 2004). Despite the correctness of rejecting one unified school or identical position, there are relevant philosophical and historical connections between these two collections of texts, such that their affinities and differences shed light on each other. For brevity's sake, I speak of Laozi and Zhuangzi as if they are the authors of the books attributed to them, although both texts have multiple-some incompatible-voices. In the case of the Zhuangzi, multiple strata have been differentiated by A. C. Graham in his introduction to Chuang-Tzu: The Inner Chapters and by Liu Xiaogan in Classifying the Zhuangzi Chapters (Ann Arbor: Michigan, 1994).

5 - Chad Hansen has demonstrated the epistemological radicalism of early Daoism, based on the Zhuangzi, in A Daoist Theory of Chinese Thought (Oxford: Oxford University Press, 1992). I examine this in detail in "Questioning Dao: Skepticism, Mysticism, and Ethics in the Zhuangzi," International Journal of the Asian Philosophical Association, 1.1, 2008: 5-19.

6 - On zhen as the self-cultivation of reality or life, see Kirkland, Taoism: The Enduring Tradition, chap. 5. Kirkland rightly differentiates two different models of how to empty oneself of desires and thoughts: (1) self-cultivation and (2) guarding and preserving one's life-forces as seen in texts such the Taipingjing 
太平经 and in Ge Hong. On the function of the zhenren 真人 in the Zhuangzi in contrast to later Daoism, see Daniel Coyle, "On the Zhenren," in Roger Ames, ed., Wandering at Ease in the Zhuangzi (Albany: State University of New York Press, 1998), pp. 197-210.

7 - Theodor Adorno and Max Horkheimer, Dialectic of Enlightenment (London: Verso, 1979), p. 9.

8 - Roth, Original Tao, p. 4.

9 - I use "dao" instead of "the Dao" in order to promote its verbal sense and avoid its reification as a substance.

10 - Adorno and Horkheimer, Dialectic of Enlightenment, p. xvi.

11 - Mencius 11.8.

12 - Ddj 2 and 64.

13 - Paper rejects "deep ecological" and "romantic" readings of Daoism in his contribution to Girardot et al., Daoism and Ecology, pp. 9-12. Xunzi's remark is in book 21 of the Xunzi.

14 - Mu-chou Poo interprets early Daoist tranquility and non-action as a response to the general anxiety and calculative concern for personal welfare, in The Search for Personal Welfare (Albany: State University of New York Press, 1998), pp. 158-160.

15 - On Zhuangzi's skepticism about concern, including the anxiety of moral concern, see Eske Møllgaard, "Zhuangzi's Religious Ethics," Journal of the American Academy of Religion 71 (June 2003) (2): 349-354.

16 - Ddj 64-67.

17 - Yuan Dao: Tracing Dao to its Source, trans. D. C. Lau and Roger Ames (New York: Ballantine Books, 1998), sec. 2, p. 63. Hereafter cited as YD, section, and page number.

18 - Norman J. Girardot argues that Daoist nature is a fluid whole irreducible to a fixed essentialistic order or to pure arbitrary chaos, in Myth and Meaning in Early Taoism: The Theme of Chaos (Hun-tun) (Berkeley: University of California Press, 1983).

19 - Like Hyun Höchsmann and Yang Guorang (Zhuangzi, p. 124), I take terms such as 神人, 真人, 至人, and 圣人 to be generally equivalent here.

20 - For an alternative and more positive reading of the environmental implications of xing in Mengzi, see Franklin Perkins, "Following Nature with Mengzi or Zhuangzi," International Philosophical Quarterly 45 (3) (2005): 327-340.

21 - On ziran as spontaneity, see Zhang Dainian, Key Concepts in Chinese Philosophy, trans. Edmund Ryden (New Haven: Yale University Press, 2002), pp. 162164. 
22 - Graham, Chuang-Tzu: The Inner Chapters, p. 156.

23 - This account of ziran is indebted to Liu Xiaogan, "Naturalness (Tzu-jan), the Core Value in Taoism," in Livia Kohn and Michael Lafargue, eds., Lao-tzu and the Tao-te-ching (Albany: State University of New York Press, 1998), pp. 211-228.

24 - Paper, in Girardot et al., Daoism and Ecology, pp. 3-4, portrays philosophy ahistorically as an isolated intellectual enterprise, remarking that "philosophies do not change culture" (p. 12).

25 - On the inclination in ancient Chinese philosophy to observe and learn from natural phenomena like water, rather than applying abstract and formulaic universal categories, see Sarah Allen, The Way of Water and the Sprout of Virtue (Albany: State University of New York Press, 1997), pp. 3, 13-14, 22-24.

26 - This differs from Dainian's account of Laozi's dao as a universal rule and objective essence, in Dainian, Key Concepts in Chinese Philosophy, pp. 15-16.

27 - Youru Wang, Linguistic Strategies in Daoist Zhuangzi and Chan Buddhism: The Other Way of Speaking (London: Routledge, 2003).

$28-\operatorname{Ddj} 23$.

29 - On responsive participation, see Ames and Hall, Daodejing: Making this Life Significant, p. 21; on mirroring, see ibid., p. 24.

30 - Ibid., pp. 68-70.

31 - Ibid., p. 23.

32 - Respectively, Ddj 5, 10, 28, 61; Ddj 1, 20, 25, 28, 51, 52, 59; and Ddj 10, 20, $28,49,52,55$.

33 - For example, Immortal Sisters, trans. and ed. Thomas Cleary (Boston: Shambhala, 1989), pp. 25 and 80.

34 - Attributed to Jie $\mathrm{Yu}$, the madman of Chu, in Zhuangzi chap. 4, Martin Palmer and Elizabeth Breuilly, The Book of Chuang Tzu (London: Penguin/Arkana, 1996).

35 - In chapter 1 (Graham, Chuang-Tzu: The Inner Chapters, p. 47), uselessness is attributed to the limitation of the one making the judgment rather than being an attribute of the object, even as many beings benefit from such partial judgments in being ignored.

36 - See Eva Wong's translation of Lieh-Tzu: A Taoist Guide to Practical Living (Boston: Shambhala, 2001), sec. 11, p. 45.

37 - Ibid., p. 44.

38 - Kirkland, Taoism: The Enduring Tradition, p. 33.

39 - Graham, Chuang-Tzu: The Inner Chapters, pp. 165-166. 
$40-Y D$ 2.67. On the de of things in early Daoism, see Dainian, Key Concepts in Chinese Philosophy, pp. 341-342.

$41-\operatorname{Ddj} 5$.

42 - English translation in Stephen R. Bokenkamp, Early Daoist Scriptures (Berkeley: University of California Press, 1997), pp. 81-82.

43 - On time as timeliness and what is seasonally appropriate, see Allen, The Way of Water and the Sprout of Virtue, pp. 11-13, and see pp. 36-37.

44 - Chapter 2 discusses the non-fixity yet meaningfulness of words, chapter 6 the non-fixity of the natural and the human.

45 - See note 52 below for a more extensive discussion of $c i$.

$46-Y D 4-5.73$.

47 - The phenomenon of dominating internal and external nature, while ideologically celebrating "nature" and appealing to it for justification, is typical of fascist ideology, as described by Adorno and Horkheimer in the Dialectic of Enlightenment.

48 - On the non-instrumental and non-calculative water-like character of wandering (xiao yao), see Allen, The Way of Water and the Sprout of Virtue, p. 83.

49 - Kirkland, "'Responsible Non-Action' in a Natural World: Perspectives from the Neiye, Zhuangzi, and Daode jing," in Girardot et al., Daoism and Ecology, 283-304.

50 - Respectively, Ddj 78; Ddj 18-20; and Ddj 30-31, 72.

$51-\operatorname{Ddj} 18$.

52 - Jordan Paper conflates the Daodejing with its reception by Hanfeizi and legalism. Admiration does not entail identity, and this conflation was already refuted during the Han period. Although the Daodejing contains some legalist elements, this should not be confused with the whole of this collection, since much of it is largely incompatible with legalism beginning with the basic difference between the wuwei of the sage-prince in the Laozi and the wuwei of the legalist monarch who "lets" things happen through the establishment of laws (fa 法), methods of control (shu 術), and authoritative power (shi 勢). In his eagerness to reduce the Daodejing to a "justification of a totalitarian state," Paper inaccurately criticizes those finding "both compassion and the rejection of coercion" in the Daodejing (Girardot et al., Daoism and Ecology, p. 9). This is false given the numerous passages deploring war and the active exploitation and endangerment of people and advocating a free, spontaneous compassion (ci, as in Ddj 67) as opposed to what is perceived as a rule-bound and ritualistically corrupted benevolence (ren). Concerning ci: Addiss and Lombardo (Tao Te Ching), Ames and Hall (Daodejing: Making this Life Significant), Blakney (The Way of Life: A New Translation of the Tao Te Ching [New York: New 
American Library, 1955]), and Victor Mair (Tao Te Ching: The Classic Book of Integrity and the Way [New York: Bantam Books, 1990]) find "compassion" in the text; James Legge (The Texts of Taoism [New York: Dover Publications, 1962]) and Michael LaFargue (The Tao of the Tao Te Ching: A Translation and Commentary [Albany: State University of New York Press, 1992]) "gentleness"; Ivanhoe (The Daodejing of Laozi) "loving-kindness"; and Arthur Waley (The Way and Its Power: Lao Tzus Tao Te Ching and Its Place in Chinese Thought [New York: Grove Press, 1958]) "pity." The discussions of force are more complicated than Paper suggests. Even as some passages seem to advocate force or acknowledge its unfortunate necessity, others speak of the force of non-force or of a non-coercive/non-intrusive force. The Zhuangzi intensifies this critique of the anxiety and concern of power, advocating anarchic responsiveness, not indifference.

53 - See Ames and Hall, Daodejing: Making this Life Significant, pp. 44-45; also compare how Ddj 43 is translated.

54 - Ames and Hall, Daodejing: Making this Life Significant, p. 42.

$55-\operatorname{Ddj} 18-19$.

56 - Paper, in Girardot et al., Daoism and Ecology, p. 9.

57 - Allen, The Way of Water and the Sprout of Virtue, p. 35.

$58-Y D 6-7.77$.

$59-Y D 7-9.77-81$.

60 - Roth, Original Tao, p. 26. Also compare Kirkland's discussion of the relation between Daoism and legalism in Kirkland, Taoism: The Enduring Tradition, pp. 26-28.

61 - Such as, respectively, Ddj 29-31,42; and Ddj 16, 27, 67.

62 - YD 9-10.81-85.

$63-Y D 12.95$.

$64-Y D 16.115$.

65 - Zhuangzi, chap. 5.

66 - Raphals, "Another View of "Responsible Non-Action," in Girardot et al., Daoism and Ecology, pp. 305-314.

67 - Ames and Hall describe this as the "one/many" metaphysics (Ames and Hall, Daodejing: Making this Life Significant, p. 12).

68 - Birdwhistell, "Ecological Questions for Daoist Thought: Contemporary Issues and Ancient Texts," in Girardot et al., Daoism and Ecology, pp. 23-44.

69 - Scott Cook describes this as the oneness of diversity or a pluralistic holism in his investigation of individual value and meaning in confrontation with the in- 
evitable and equalizing character of death. Asking whether the panpipes of heaven (tianlai) is a celebration of life or mere noise, it is paradoxically by forgetting the self that one learns to listen to this symphony of life and death such that oneness is found in the diversity and harmony in the cacophony. See his "Harmony and Cacophony in the Panpipes of Heaven," in Scott Cook, ed., Hiding the World in the World (Albany: State University of New York Press, 2003), pp. 64-87.

70 - Karyn Lai, "Conceptual Foundations for Environmental Ethics: A Daoist Perspective," Environmental Ethics 25 (3) (Fall 2003): 247-266.

71 - Ames and Hall point out that dao implies the mutuality of the singular and the whole rather than the dominance of one term (Ames and Hall, Daodejing: Making this Life Significant, p. 11).

72 - Asserting that each perspective is true is not theoretical but a self-referential and pragmatic truth confirmed by its performative demonstrability in any given perspective. The oneness of things is hence the denial of definite knowledge and the possibility of responsively wandering free and at ease in a transforming world. See Brook Ziporyn, "How Many Are the Ten Thousand Things and I? Relativism, Mysticism, and the Privileging of Oneness in the 'Inner Chapters,'"' in Cook, Hiding the World in the World, pp. 33-63.

73 - Ddj 40. Ivanhoe translates fan as "turning back." Dainian also discusses it as "return" and "opposition" (Dainian, Key Concepts in Chinese Philosophy, pp. 119-120).

74 - See Isabelle Robinet's discussion of reversal in "The Diverse Interpretations of the Laozi," in Mark Csikszentmihalyi and Philip J. Ivanhoe, eds., Religious and Philosophical Aspects of the Laozi (Albany: State University of New York Press, 1999), pp. 144-146.

75 - For an insightful explanation of the kind of dialectic involved in later yin-yang philosophy, the notion of natural harmony in contrast to imposed unity, its ethical implications, and its misinterpretation as hierarchical subordination, see Robin Wang, "Dong Zhongshu's Transformation of Yin-Yang Theory and Contesting of Gender Identity," Philosophy East and West 55 (2) (April 2005): 209-231, and "Zhou Dunyi's Diagram of the Supreme Ultimate Explained (Taijitu shuo): A Construction of the Confucian Metaphysics," Journal of the History of Ideas 66 (3) (July 2005): 307-323.

76 - In addition to $D d j 8,15,16,66$, and 78, see YD 14.103-105.

77 - Allen, The Way of Water and the Sprout of Virtue, p. 31.

78 - Karyn Lai, "The 'Daodejing': Resources for Contemporary Feminist Thinking," Journal of Chinese Philosophy 27 (2) (June 2000): 131-153.

79 - Allen, The Way of Water and the Sprout of Virtue, pp. 46-47. 